\title{
Author Correction: Mechanically tunable conductive interpenetrating network hydrogels that mimic the elastic moduli of biological tissue
}

\author{
Vivian R. Feig (1D) ${ }^{1}$, Helen Tran $^{2}$, Minah Lee (iD ${ }^{2} \&$ Zhenan Bao (iD ${ }^{2}$
}

Correction to: Nature Communications; https://doi.org/10.1038/s41467-018-05222-4; published online: 16 July 2018

The original version of this Article contained an error in the second sentence of the 'Materials' section of the Methods, which incorrectly read 'PEDOT:PSS synthesized by Orgacon (739324 Aldrich, MDL MFCD07371079) was purchased as a surfactant-free aqueous dispersion with $1.1 \mathrm{wt} \%$ solid content.' The correct version replaces this sentence with 'PEDOT:PSS Orgacon ICP 1050 was provided by Agfa as a surfactant-free aqueous dispersion with $1.1 \mathrm{wt} \%$ solid content.' This has been corrected in both the PDF and HTML versions of the Article.

Published online: 23 November 2018

(c) (i) Open Access This article is licensed under a Creative Commons Attribution 4.0 International License, which permits use, sharing, adaptation, distribution and - reproduction in any medium or format, as long as you give appropriate credit to the original author(s) and the source, provide a link to the Creative Commons license, and indicate if changes were made. The images or other third party material in this article are included in the article's Creative Commons license, unless indicated otherwise in a credit line to the material. If material is not included in the article's Creative Commons license and your intended use is not permitted by statutory regulation or exceeds the permitted use, you will need to obtain permission directly from the copyright holder. To view a copy of this license, visit http://creativecommons.org/licenses/by/4.0/.

(c) The Author(s) 2018

\footnotetext{
${ }^{1}$ Department of Material Science and Engineering, Stanford University, 443 Via Ortega, Room 307, Stanford, CA 94305, USA. ${ }^{2}$ Department of Chemical Engineering, Stanford University, 443 Via Ortega, Room 307, Stanford, CA 94305, USA. Correspondence and requests for materials should be addressed to Z.B. (email: zbao@stanford.edu)
} 